\title{
Optimization of process of application plasma hardening coating
}

\author{
Evgeniy Smolentsev ${ }^{1, *}$, Anvar Kadyrmetov², and Mikhail Kondratyev ${ }^{1}$ \\ ${ }^{1}$ Voronezh State Technical University, 394026 Voronezh, Moskovskiy.pr.14, Russia \\ ${ }^{2}$ Voronezh State Forestry University of G. F. Morozov, Timiriaziva 8, Russia
}

\begin{abstract}
This article addresses the problem of increasing tool life by applying a wear-resisting coating. However, the lack of technology-based methods and optimal regimes complicate this process. A method for finishing plasma hardening of metals which allows evaluate the quality of the wear-resistant thin-film coatings and optimize application regimes have been advanced.
\end{abstract}

Development of high-tech economic sector is a crucial state objective for national technological security and independence, including development of knowledge-intensive industries as well as traditional industries $[1,2]$. These issues became particularly relevant under current circumstances of sanctions and export limitations [3]. The General Director of "VNIIINSTRUMENT" G.V. Borovskiy stressed that most specialists are scared of fundamental dependence on cutting instruments importation; this situation may lead to the machines shutdown and the collapse of the entire Russian industry. Tool importation reach $95 \%$ [4].

At this moment, when import substitution is needed and under developing tendency for lowering production costs at machine-building enterprises, increase of tool life becomes an actual direction of improving production efficiency.

Among the many means to increase a metal-cutting tool life, relatively promising techniques, due to comparatively low costs, reusability and ease of use, involve the method of applying a wear-resistant coatings to a tool cutting part $[5,6]$.

However, given the great variety of types, shapes, sizes and materials of a tool cutting part, the use of methods of applying wear-resistant coating, including diamond-like carbon coatings, is discouraged by the lack of technology-based methods and optimal regimes of application, control over application time, resulting coating thickness and quality. In the process of applying coating, even the slightest deviation from optimal regimes may significantly lower the coating quality $[7,8]$.

The proposed method of finishing plasma hardening allows evaluate the quality of applying the wear-resistant thin-film coatings to the tool cutting part and optimize application regimes in order to achieve optimal results.

To apply coating we chose finishing plasma hardener FPU-114 (ФПУ-114), which allows applying of wear-resisting thin-film diamond-like carbon coating to different

\footnotetext{
*Corresponding author: 540520@mail.ru
} 
samples. The coating based on silicon oxycarbide is a product of plasma chemical reactions of reagents vapor, processed by arc plasma torch. We added special additives in suspension to carrier argon to make a coating.

Before applying a coating, we made a precleaning of a base, its degreasing and heating. As the most influential factors in the coating process, we chose parameters that were capable of the greatest impact on the final result, namely, the parameters of surface preparation quality, surface preheating temperature, the amount of reactant supplied at a fixed flow of plasma-forming argon, the distance from the plasma torch to the surface being hardened and coating time. As the criteria of the process, we used the adhesion coefficients $\mathrm{Sa}$ and cohesion Sk, the hardness and microhardness of the coating NDC (non-destructive control).

As the tested samples, we chose discs with a diameter $50 \mathrm{~mm}$ and thickness $10 \mathrm{~mm}$ of steel 45, which allow assessing the quality of coating. For a comparative evaluation of the adhesion value, we used a sclerometric method for determining the adhesion strength, and a microhardness tester PMT-3M (ПTM-3M) with the Knup pyramid to measure the microhardness, which made it possible to measure extremely thin coatings or brittle materials.

The quality of surface preparation was determined by comparing four types of materials for surface cleaning: gasoline "Kalosha", cleaner, alcohol, gasoline "Kalosha" with alcohol. The surface of the fifth sample was not degreased. After degreasing the substrates, the samples were heated in the furnace to $800^{\circ} \mathrm{C}$. The delivery of the carrier gas was 0.4 $1 / \mathrm{min}$, and the supply of the plasma-forming gas was $3 \mathrm{l} / \mathrm{min}$. The distance from the plasma torch nozzle to the surface of the samples was $12 \mathrm{~mm}$. After testing the surface of samples for adhesion, we chose the most optimal variant of preparation of substrates: degreasing with a universal purifier TU 2384-010-50161205-2003 (Figure 1), which provides values of adhesion coefficients $\mathrm{Sa}=0.15$ and cohesion $\mathrm{Sk}=0.08$. Slightly inferior to this cleaner on the quality of surface preparation are alcohol and a mixture of alcohol with "Kalosha" gasoline. As expected, the lowest values of the coefficients are characterized by the absence of any treatment, at which $\mathrm{Sa}=0.51, \mathrm{Sk}=0.36$.

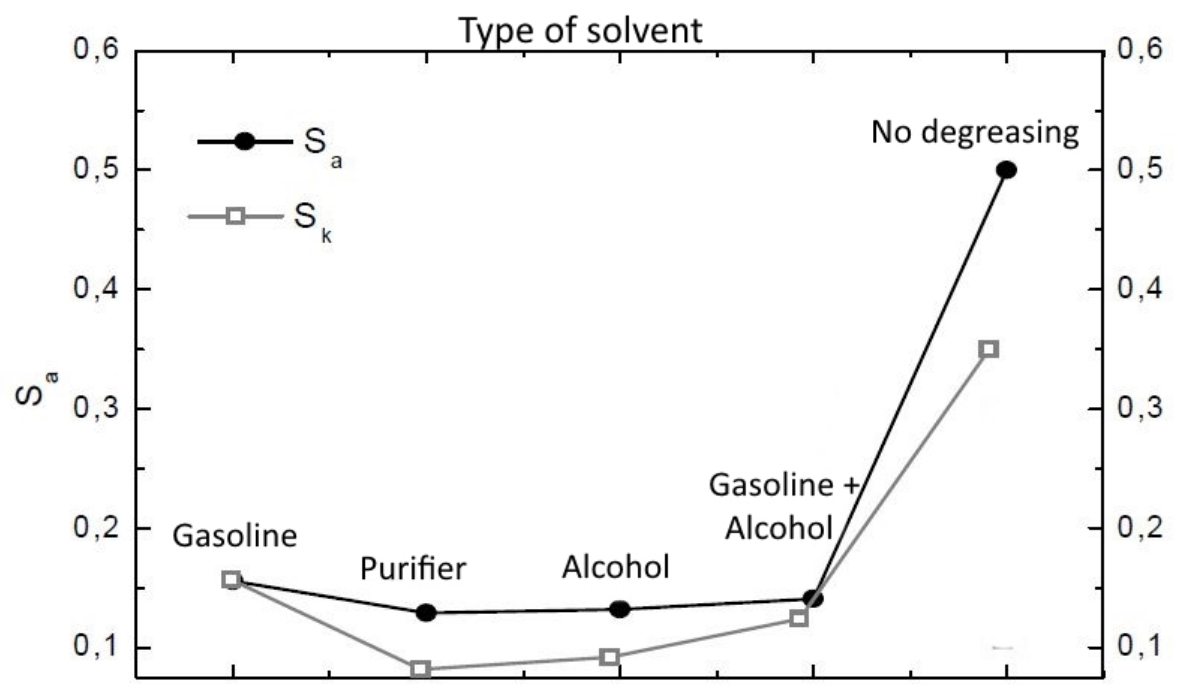

Fig. 1. Coating coefficients Sa and Sk dependence on the type of solvent. 
To determine the optimal preheating temperature, we heated six samples in the furnace to different temperatures: $80^{\circ} \mathrm{C}, 110^{\circ} \mathrm{C}, 130^{\circ} \mathrm{C}, 170^{\circ} \mathrm{C}, 200^{\circ} \mathrm{C}$ and $230^{\circ} \mathrm{C}$. The surface of the sixth sample after heating to $230^{\circ} \mathrm{C}$ acquired a yellowish shade, which indicates the oxidation of the surface. On each of the samples we made 4 spot coatings of the hardening coating. The time of the first three depositions on the surface of each sample was as follows: $15 \mathrm{~s}, 30 \mathrm{~s}$ and $60 \mathrm{~s}$. The time of the fourth point deposition varied on each sample from $180 \mathrm{~s}$ to $300 \mathrm{~s}$. The best results were obtained for the spraying time of $60 \mathrm{~s}$. The results of testing the samples for adhesion properties and microhardness for the spraying time of $60 \mathrm{~s}$ are shown in Fig. 2 and Fig. 3. These figures suggest that, according to the strength criteria for adhesion and cohesion, the optimal heating temperature is the temperature $115^{\circ} \mathrm{C}(\mathrm{Sa}=0.02, \mathrm{Sk}=0.025)$, and by hardness - temperature $130^{\circ} \mathrm{C}(\mathrm{HDC}=$ $560)$.

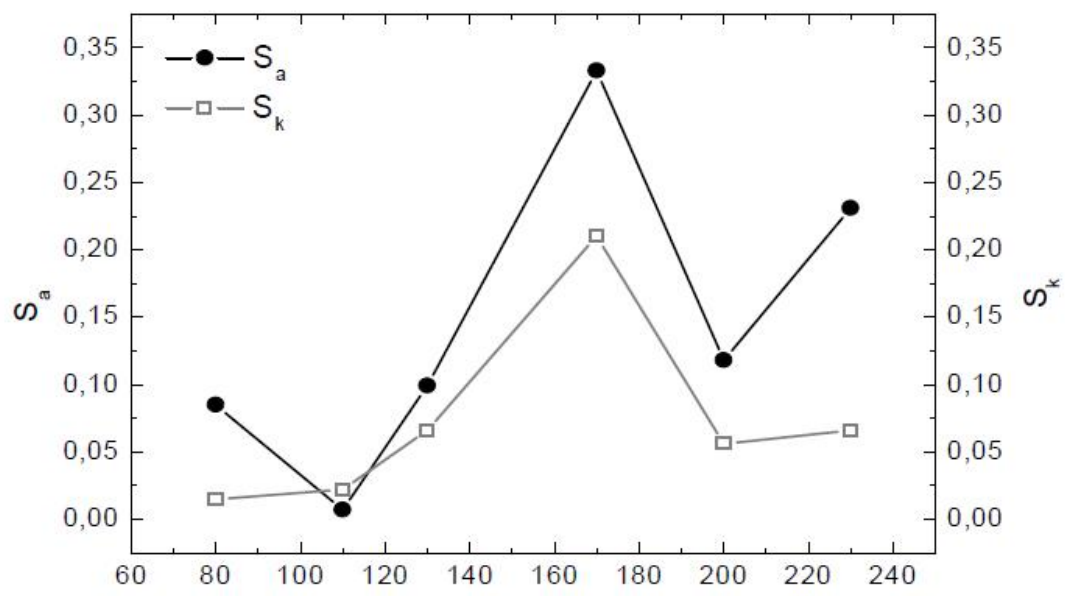

Fig. 2. Coating coefficients Sa and Sk dependence on the preheating temperature of a substrate in the furnace (spraying time $60 \mathrm{~s}$ ).

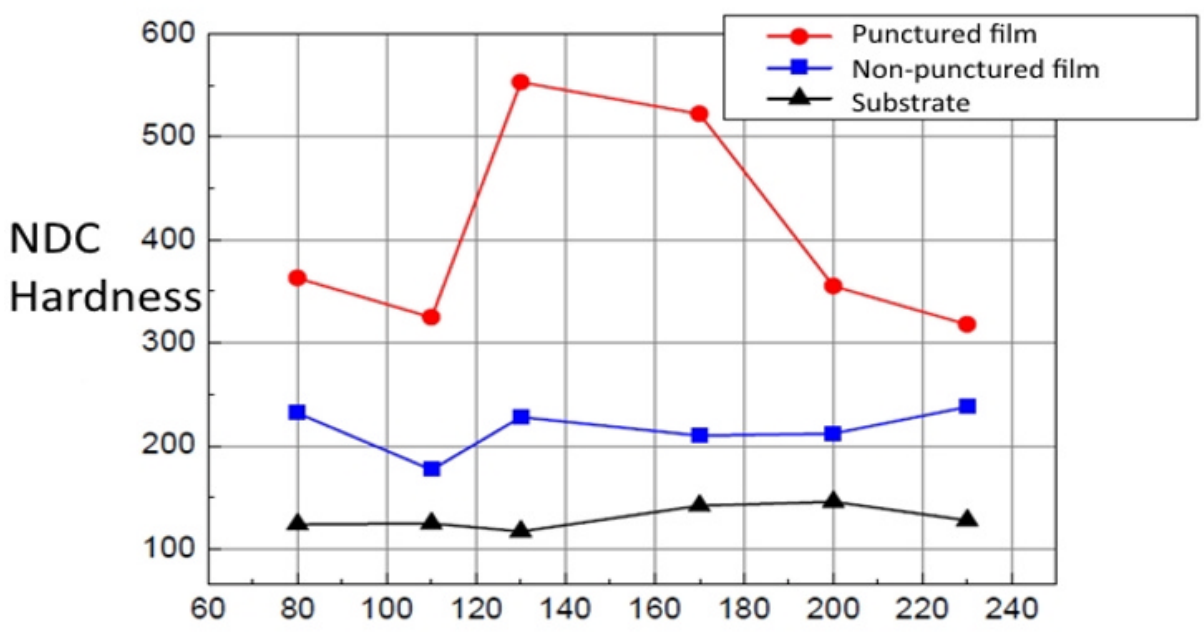

Fig. 3. Diagram of changes in NDC hardness dependence on the preheating temperature of a substrate in the furnace (spraying time $60 \mathrm{~s}$ ).

In order to choose the most optimal type of sample preheating, besides the examined variant of heating in the furnace, experiments were also carried out for the following 
options: without heating in the furnace and without plasma treatment, without heating in a furnace with plasma treatment, a combined oven-heated and plasma-heated variant. The combined heating of the test samples was that the surface of a sample preheated in the furnace to $130^{\circ} \mathrm{C}$ for 60 seconds was treated with plasma, with a plasma gas supply of $2.75 \mathrm{l} / \mathrm{min}$ when the sample was rotated in a three-jaw chuck. The time of surface treatment of the sample with plasma was 5 minutes. According to the results of the investigation of adhesion properties, the preferred option was the preheating option in a furnace without plasma treatment. The difference in microhardness of sample surfaces with standard heating in a furnace and combined heating was a value commensurate with measurement errors. Therefore, heating in the furnace for 60 seconds at $115-130^{\circ} \mathrm{C}$ without additional plasma heating is optimal.

Varying the amount of the reactant supplied was accomplished by varying the flow rate of the carrier gas. The flow rate of the carrier gas varied in the range from 0.3 to $0.61 / \mathrm{min}$. The supply of the plasma-forming gas did not vary and was $2.751 / \mathrm{min}$.

The distance from the nozzle of the plasma torch to the sample surface was $7 \mathrm{~mm}$. Spraying was pointy, each point was being sprayed for 20 seconds. The maximum value of microhardness - 2091 hardness units - was obtained at a flow rate of the transport gas of 0.4 $\pm 0.05 \mathrm{l} / \mathrm{min}$.

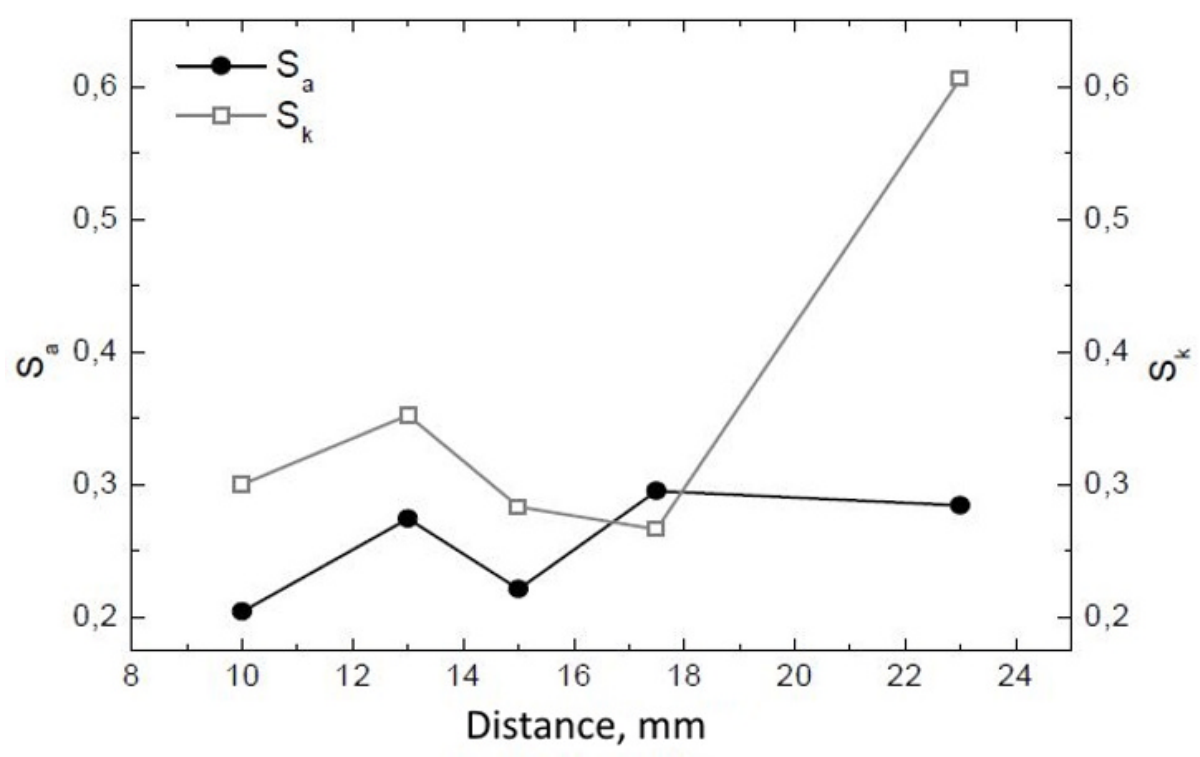

Fig. 4. Coating coefficients Sa and Sk dependence on the distance from the nozzle of the plasma torch to the substrate surface. 


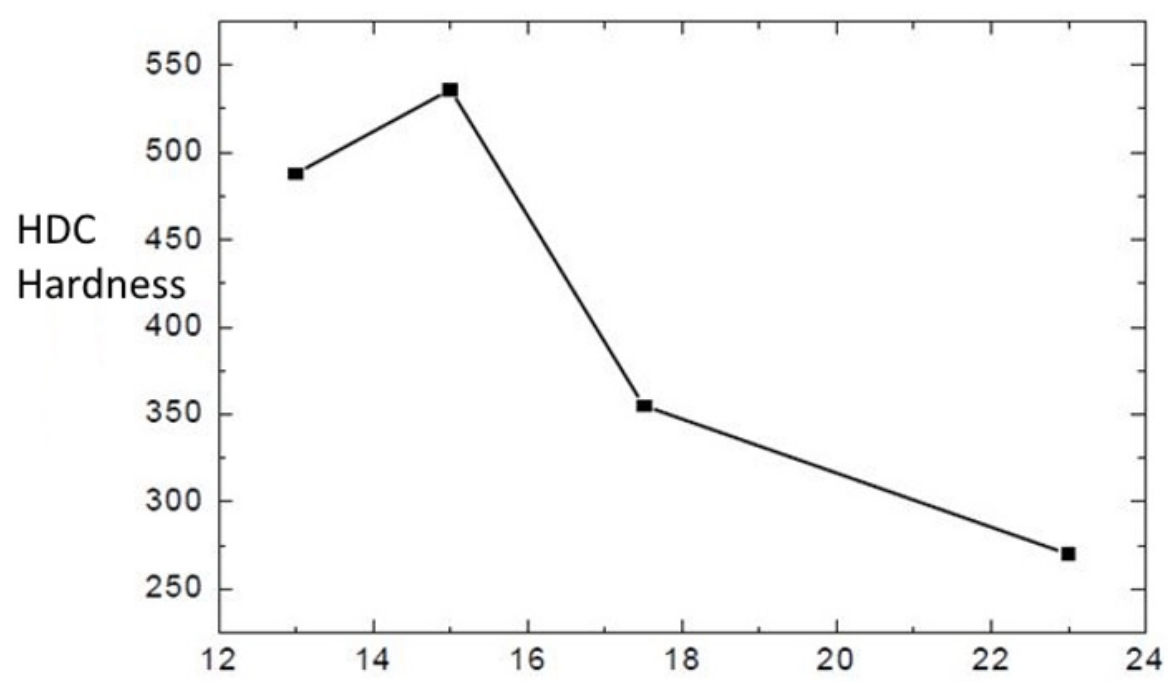

The distance from the nozzle of the plasma torch to the substrate, $\mathrm{mm}$

Fig. 5. NDC hardness dependence on the plasma torch - substrate distance.

The impact of the spraying distance in the range from $5 \mathrm{~mm}$ to $23 \mathrm{~mm}$ on the quality criteria for the coating is shown in Fig. 4 and Fig. 5. The tests were carried out at a flow rate of the carrier and plasma-forming gas of $0.71 / \mathrm{min}$ and $2.75 \mathrm{1} / \mathrm{min}$, respectively. Spraying had pointy nature, each point was sprayed for $60 \mathrm{~s}$. The best adhesion properties had samples obtained at distances of $10-17.5 \mathrm{~mm}(\mathrm{Sa}=0.2-0.26, \mathrm{Sk}=0.28-035)$ (Figure 4). The maximum hardness value was NDC $=560$, microhardness -2147 hardness units at a distance from the nozzle of the plasma torch to the surface of the sample equal to $15 \mathrm{~mm}$ (Fig. 5). Thus, the investigated impact of the factors of the finish plasma hardening of samples in steel 45 on the strength characteristics and hardness of oxycarbide film coatings showed that the optimal ranges for the values of the factors are the following intervals: by preheating the samples in the furnace at a temperature of $115-130^{\circ} \mathrm{C}$, at a spraying distance of $10-17.5 \mathrm{~mm}$, at the consumption of the carrier gas $-0.4 \pm 0.051 / \mathrm{min}$. Resulting coatings will have strength characteristics with hardness in the following ranges: $\mathrm{Sa}=0.02-0.26, \mathrm{Sk}$ $=0.025-035, \mathrm{NCD}=350-560$.

To obtain narrower optimal ranges of factors for the finish plasma treatment and taking into account other factors, such as the power of the plasma torch, the velocity of the plasma torch relative to the substrate, the consumption of the plasma-forming gas and additional additives to it, a multifactor experiment is necessary. This will make it possible to predict the properties of the coating for each specific application.

\section{References}

1. Ye.YU. Stepanova, L.I. Polandova, Vysokiye tekhnologii v innovatsionnoy ekonomike, Fundamentalnyye i prikladnyye problemy tekhniki i tekhnologii, № 3, pp.156-167 (2007)

2. Ye.YU. Stepanova, Naukoyemkiye otrasli $i$ vysokiye tekhnologii - osnova tekhnologicheskoy bezopasnosti i nezavisimosti strany, Fundamentalnyye i prikladnyye problemy tekhniki i tekhnologii, № 2 (304), p. 122-132 (2014) 
3. Ye.YU. Stepanova, Eksportnyye ogranicheniya SSHA $i$ YES kak stimul $k$ razvitiyu naukoyemkikh $i$ vysokotekhnologichnykh sektorov ekonomiki, Fundamentalnyye i prikladnyye problemy tekhniki i tekhnologii, № 3 (305), pp. 96-103 (2014)

4. M. Fokin, Stanki pod kontrolem zagranitsy. - URL: http://rusplt.ru/society/stanki-podkontrolem- zagranitsyi-15840.html. - Data obrashcheniya: 20.05.2015

5. N.A. Sosnin, S.A. Yermakov, P.A. Topolyanskiy, Plazmennyye tekhnologii. Rukovodstvo dlya inzhenerov (SPb.: Izd-vo Sankt-Peterburgskogo politekhnicheskogo universiteta, 2008)

6. P.A. Topolyanskiy, Opyt naneseniya elektroiskrovykh pokrytiy na rezhushchiy instrument $i$ shtampovuyu osnastku, Metalloobrabotka, № 6(24), pp. 37-40 (2004)

7. A.M. Kadyrmetov, G.A. Sukhochev, Osobennosti protsessa vozdushno-plazmennogo naneseniya i uprochneniya pokrytiy, Uprochnyayushchiye tekhnologii i pokrytiya, № 4 (52), p. 25-28 (2009)

8. A.M. Kadyrmetov, Issledovaniye protsessov plazmennogo naneseniya i uprochneniya pokrytiy $i$ puti upravleniya ikh kachestvom, Politematicheskiy setevoy elektronnyy nauchnyy zhurnal Kubanskogo gosudarstvennogo agrarnogo universiteta, № 81, pp. 308-325 (2012) 